\title{
Comparison of Trademark Laws as Fiduciary Guarantee Objects
}

\author{
Anis Mashdurohatun ${ }^{1 \mathrm{a}}$, Gunarto $^{\text {1b }}$ \\ Faculty of Law, Universitas Islam Sultan Agung (UNISSULA), Semarang, Indonesia \\ a anism@unissula.ac.id, ${ }^{\mathrm{b}}$ gunarto@unissula.ac.id
}

\begin{abstract}
With the increasing of goods and services, in line with the increasing of national economic growth. Some of the countries which the economic activity and trade is no longer rely on products derived from natural resources, but rely more on human intellectual ability, especially products of intellectual property such as trademarks. In the midst of the national economy, of course, backed by venture capital from banks with a strong guarantee institution. The purpose of this study was to examine and analyze the classification of trademarks as a Fiduciary goods, and Comparative Law of Trademarks as Fiduciary Warranty. The approach method in this research is a social law. The data used are primary and secondary data. The data analysis used descriptive analytic. The results showed that the classification of trademarks as places are trademarks Fiduciary is one of the objects of intellectual property rights set forth in the Act No. 20 of 2016 concerning the brand and geographical indications. Intellectual Property as the right material, which can be divided means can be transferred in whole or in part to any other party. Transfer whole or in part is shown by actions taken in connection with the exercise of the right, through the Heritage; Grant; Will; Written agreement; or other causes that are justified by law. With such classification trademark qualifies as one of the objects fiduciary. In some developed countries, particularly the United States has implemented the intellectual property potential, especially in the trademark as the function of the strong safety object of fiduciary, such as KFC, Starbuck, Coca-Cola, etc.
\end{abstract}

Keywords-Comparative law; Trademark; Fiduciary

\section{INTRODUCTION}

The influence of globalization in all areas such as in the social, economic, and culture increasingly driving the pace of economic development of society. The economy is one of the three main pillars of development in the social and political side. ${ }^{1}$, With the increasing development activities, increased also the need for the availability of funding, mostly obtained through lending activities. The importance of the position of the credit funds in the development process, it should if the giver and the recipient of credit and other relevant parties are protected by a strong guarantee rights institutions and which can also provide legal certainty for all parties concerned. ${ }^{2}$

Lending activities is the task of the bank in disbursing funds to the community. Where the Bank as a business entity that collects funds from the public in the form of savings and channel them to the public in the form of credit and/or other forms in order to improve the standard of living. ${ }^{3}$ Trade Traffic requires a guarantee of secure rights to something as well as a law enforcement execution. ${ }^{4}$ Creditors need of certain objects designated for credit or a loan, in other words creditors require any special guarantee for him that is immaterial and individuals ${ }^{5}$. Improving business development in many countries provides an opportunity for the intellectual property to play its role as collateral. Intellectual property as a mechanism guaranteeing the security of goods necessary to obtain the support of good legislation and to provide legal certainty for the parties. ${ }^{6}$ Increasing the bussiness in many countries give the opportunities to Intellectual product like as a Property Right. This mechanism need the support from the goverment and certainty of the law. ${ }^{7}$

IPR is the material right, the right to an object that comes from the brain work, the work of the ratio of human reasoning. The work of the reasoning ratio is in the form of immaterial objects that are intangible objects. Indonesia to become the WTO's member to ratify the TRIPS Agreement in 1994. This matter raises the consequence that for makes IPR Regulation and has an obligationall the members to provide IPR protection against countries that are members of the WTO. ${ }^{9}$ By basing the HKI (Hak Kekayaan Intelektual; Indonesian language; Intellectual Property Right in English) as part of the object that is intengible law and that their rights can be switched/ transferred, which corresponds to the characteristics and types can be used as collateral. Hence the need for legal certainty that every citizen who has a certificate of HKI in the form of Copyright, Patent, Trademark, Trade Secret, Industrial Design and Layout Design of Integrated circuits, can be used as collateral in financial institutions. Especially those engaged in the UMKM trademark can be used as guarantee. Results of the Identification Department of Cooperatives and UMKM, the UMKM much constrained in the manufacture of products, lack of partnerships with financial institutions as well as limitations in the development of regional and global markets. Therefore, UMKM need to obtain capital and banking institutions require collateral security object as 
their capital back. Which raised the question in this study, how Classification trademark as an object fiduciary banking institution and comparison of trademark law as an object fiduciary banking institution.

\section{RESEARCH METHOD}

Patterns of this study used a qualitative research method ${ }^{10}$, using this method are expected to be discovered the hidden meanings behind the object under study. With the approach of juridical sociological research, will identify and conceptualize law as real and functional institutions in the system of social life that is patterned. ${ }^{11}$ The data used is secondary data was done by means of literature study as well as a comparative study, a series of attempts to obtain the data with the read, examine, classify, identify, and conducted understanding of legal materials in the form of rules, conventions and literature which is relevant to the issues raised. ${ }^{12}$

The results of the assessment activity is then analyzed systematically as the epitome of studies document the assessment results. And primary data is data obtained from the field through interviews and focus group discussions. Furthermore, in more detail the data obtained from the study, good library research or field study, processed and analyzed critically and analytically presented descriptively qualitative. The collection of data (quantitative and qualitative data), then data reduction, dispaly data and ending with the formulation of conclusions. To determine the accuracy and reliability of the data it uses data triangulation technique.

\section{RESULTS AND DISCUSSION}

\section{A. Classification Trademark as an Object Fiduciary in the Banking Institution}

In general, the objects are divided into three groups: tangible objects and intangible objects, movable objects and immovable objects, and objects that can be spent and objects that can not be spent. Regarding tangible objects and intangible objects set out in Article 503 of the Civil Code which states that every material are tangible and intangible. "Objects" referred to in the Civil Code is a tangible objects such as vehicles, land and others. While intangibles such as copyright, trademark, patent, are not regulated by the Civil Code but governed by a separate Act.

Object definition can be found in Article 499 of the Civil Code which states that the definition of objects or "zaak" is anything that can be the object of property rights. Which can be the object of property rights can be in the form of goods and may also be the rights, such as copyrights, trademarks, patents and others. The definition of property rights itself contained in Article 570 of the Civil Code which states that property rights is the right to enjoy the usefulness of a material freely, and to act independently of the material with full sovereignty, the origin is not awry with the laws or regulations of a common set by an authority entitled to set them, and do not interfere with the rights of others; The object of property rights as defined in Article 570 of the Civil Code is the object that has economic value. It is expressly provided for in Article 1131 of the Civil Code which states that all physical objects, moving and unmoving belong debtor, either existing or to be there, to be a guarantee for the engagement the individual debtor. With the provision contained in Article 1131 of the Civil Code, it is clear that the only material that has economic value that can serve as collateral for the implementation of the commitment, obligation nan for implementation engagements, obligations, achievements, or debt of a debtor. ${ }^{13}$

The provisions of Article 1, paragraph (1), (2) and (5) of Act No. 20 of 2016 on the brand and geographical indications, explain the meaning of the brand, trademark and brand rights. The brand is a sign that can be displayed graphically in the form of images, logos, names, words, letters, numbers, color composition, in the form of two (2) dimensional and / or 3 (three) dimensions, sound, hologram, or a combination of the two (2) or more of these elements to distinguish the goods and / or services produced by the person or legal entity in the trading of goods and / or services. Trademark is a brand used on goods traded by a person or persons jointly or a legal entity to differentiate with other similar items.

The function of the brand itself, as stated by Michael Grynberg ${ }^{14}$ is:

"Trademarks exist to identify and distinguish goods. Use of Brand produces a variety of benefits, such as preventing fraud, lowers search costs of goods, encouraging investment in quality by ensuring that consumers know who should be credited for producing a superior product. It helps brand owners build goodwill with consumers. They allow sellers to efficiently convey information about their products (with the advertising attributes about them), and they allow others to do the same (by word of mouth, consumer reviews, or the like). In other words, once a source of brand identification function is set, then the "mark" has become an efficient vehicle for establishing a connection between the brand owner and consumer.

Trademarks are the property of the formless movable objects and has economic value. The economic value contained in the trademark can be seen from the brand owner's right to license its brand to other persons accompanied by the payment of royalties. In addition, the economic value contained in the brand can also be seen from the level of customer satisfaction and benefits. If we look at the notion of objects, then there are two main elements that must be met in order for something to be categorized as objects referred to in Article 499 of the Civil Code, namely: Is Having a property and economic value.

In addition, according to J. Satrio ${ }^{15}$ indicating that the collateral material, in accordance with the properties of the right material, has characteristics typical include: having a direct connection with / on certain objects belonging to the debtor, can be maintained or addressed to anyone (everyone), has the properties droit de suite, meaning that the right to follow the object in the hands of whoever is, and older have a higher position, and transferable/transferred to another person. 
Fiduciary or fiduciary Eigendom Overdracht (FEO) is one form of collateral material well known in the business life. In essence fiduciary transfer of ownership rights is an object on the basis of trust, provided that the objects transferred ownership rights, remain in control of the owner of the object (the debtor) ${ }^{16}$, Construction law makes constitutum possessorium fiduciary creditors as assignee, material property as collateral, only receive them confidence. This means fiduciary material remains in the hands of the debtor, while creditors only mastered the letters material proof of ownership of the hands of the debtor submitted to creditors ${ }^{17}$, Fiduciary initially set in Jurisprudence decision, namely: in 1931 the HGH arrest of BPM Case Clignet in the days of the Dutch East Indies. Then last in the decision of the Supreme Court of the Republic of Indonesia No. 372 K / Sip / 1970 September 1, 1971, decision of the Supreme Court of the Republic of Indonesia $227 \mathrm{~K} / \mathrm{Sip} / 1977$, February 2, $1980^{18}$. Fiduciary guarantee as described experts are due to many shortcomings expansion pawn institutions (pand) in meeting the needs of society and not be able to follow the development in society ${ }^{19}$. Fiduciary is a term that has long been known in the Indonesian language. The law governing this matter, namely Act No. 42 of 1999 also uses the term "fiduciary". Thus, the term "fiduciary" is already an official term in the world of law in Indonesia. However, in the Indonesian language, to the fiduciary is also called "Delivery Properties In Trust".

In the Dutch terminology often referred to as full namely Fidusiare Eigendom Overdracht (FEO), whereas in the English language is complete is often referred to as Fidusiary Transfer Of Ownership ${ }^{20}$.

In Article 1, paragraph (1) of Act No. 42 of 1999 regarding Fiduciary, the definition of a fiduciary is "The transfer of ownership of an object on the basis of trust with the provision that the object held ownership rights is still in control of things" ${ }^{\prime 2}$.

Object fiduciary prior to the enactment of Act No. 42 of 1999 (hereinafter Fiduciary Insurrance Law) in general is movable objects comprising objects inventory, merchandise items, accounts receivable, equipment machinery and motor vehicles. However, since the enactment of Fiduciary Insurrance Law understanding of fiduciary expanded so that is the object of fiduciary includes objects moving tangible or intangible and immovable that can not be burdened with mortgage according to Act No. 4 of 1996 on Mortgage objects associated with the ground. In Article 1 paragraph 4 of Fiduciary Insurrance Law mentioned that Matter is anything that can be owned and transferred, whether it tangible or intangible.

According to the Act No. 1999.42 of fiduciary, fiduciary security object is divided into 2 types, namely: Movable objects; and Immovable objects. Then, the subject of a fiduciary is a fiduciary giver and receiver. Giver fiduciary is an individual or corporate owner of the object which is the object fiduciary, while the personal receiver of fiduciary is a person or corporation that has a receivable for which payment is guaranteed by fiduciary. Prior to the enactment of Fiduciary Law, the existence of a fiduciary as a guarantee institution recognized by jurisprudence. Construction of fiduciary based jurisprudence ever there was a handover of ownership of the trust, on objects or goods to move (belonging to the debtor) to creditors with physical control over the goods that remain on debtors ${ }^{22}$.

According to A. Hamzah and Sarjun Manullang, fiduciary sense is a way to transfer the property of its owner (debtor), based on the existence of a principal agreement (agreement of debts) to the creditor, but the only right handed only in trust (as collateral for the debtor) , while the goods are still controlled by the debtor but not anymore as eigenaar (owner) and bezziter (position in power) but only as detentor or houder (the master object) and on behalf of the creditor eigenaar ${ }^{23}$

Funir Fuady stated, the fiduciary is the delivery of property rights in trust ${ }^{24}$, Gunawan Widjaja and Ahmad Yani interpret fiduciary derived from the word "fides" which means belief ${ }^{25}$, In addition to the term fiduciary, also known as the term fiduciary. The term fiduciary is known in Article 1 paragraph 2 of Act No. 42 of 1999 on Fiduciary, namely "Rights guarantee of movable objects both tangible and intangible and immovable in particular building can not be encumbered encumbrance as intended in Act No. 4 of 1996 on mortgage which remain in control of fiduciary giver, as collateral for the repayment of certain debt, which gives precedence to the receiver position fiduciary against other creditors $" 26$.

Based on the Decree of the Ministry of Law and Human Rights, the Directorate General of Legal Administration to the Regional Office of the Department of Law and Human Rights of Jakarta No. C. HT. 06-10-01 dated February 24, 2010, it is stated that: (1) The object of fiduciary guarantee is a material right; (2) The project terms, leases, contracts or borrowings and other personal rights are not understood as objects of fiduciary security; (3) The insurance policy shall not be subject to fiduciary security because of the insurance / insurance policy that is the inherent right of the person who owns it but is not transferable. In essence, the fiduciary guarantee is an object the which ownership rights may own and transfer from, whether tangible or intangible, registered or unregistered, mobile or immovable, the which can not be borne by mortgages. On the other hand, the object of fiduciary assurance, especially on intangable objects, has a significant development ${ }^{27}$.

HKI is part of the ownership of the movable objects are intangible ${ }^{28}$. Indonesian trademark protection through Act No. 20 of 2016 on the brand and geographical indications, is part of the Intellectual Property Rights (HKI). In Article 41 paragraph (1) of the Trademark Act explains that the right to a registered Mark may be transferred because: a. inheritance; b. will; c. endowments; d. grant; e. agreement; or f. Another reason is justified by the legislation. fiduciary is very closely related to the credit agreement of the bank, when the debtor wants to borrow money from the bank to expand its business by providing assurance of moving objects, Because The debtor has no guarantee of other objects. ${ }^{29}$ Banks need to assess the loan application by reviewing $5 \mathrm{C}$, which are: Collateral. $^{30}$ 
Thus the trademark as part of the HKI are property rights on the movable objects are intangible ${ }^{31}$ and can be switched and transferred to other parties as well as economic value, qualify as an object of fiduciary under Article In Article 1 paragraph 4 of Fiduciary Insurrance Law.

\section{B. Comparative Law of Trademarks As Object Fiduciary At the Institute of Banking}

HKI is one of the factors that affect the welfare of the human capital of a nation. As for some of these factors is the first capital: Natural Capital; water, earth, wood, minerals and so on, both: Physical Capital; Machinery, buildings, factories, public facilities, third: Human Capital; the value of human productive, Intellectual Property Rights (HKI) and fourth: Social Capital: the values of family, community, various organizations set up within society $^{32}$

The value and importance of intangible assets are the driving force behind national and international Mergers and are playing a greater role than ever before in terms of assets received through Mergers, acquisitions and takeovers. Among These intangible assets are the traditional intellectual property assets such as patents, trademarks, copyrights, know-how and trade secrets. More recently included in this category and of ever-increasing importance are mask-works and Internet domain names. In the event of a merger or other type of corporate restructuring, the acquiring party should Obtain equitable and record ownership of Reviews These intangible assets, or at the very least, acquire the Appropriate license to use such intellectual property. ${ }^{33}$

In 2007, concluded UNCITRAL Legislative Guide which provides advice on the legal regime of uniform for secured financing, which also includes IP financing. The legislative guide should be considered in the context of the previous policy by UNICTRAL, including the United Nations Convention on the Assignment of Receivables in International Trade and the Model Law on Cross-Border Insolvency. Form of security that can be provided on intellectual property (registered and unregistered) are liens. ${ }^{34}$ Only the intellectual property rights which have no legal basis and is transferable unreliable. Intellectual Property Rights included in the capital to individuals and / or groups to create a business or looking for a profit apart from the economic capital and natural resources that are generally used by the public. As was mentioned earlier that according to Kotler, HKI is a human capital included in the factors that affect the wellbeing of a nation but it is also in the international world of HKI already have a mechanism where HKI is protected even not only protected from the perspective of the juridical where protection only given only legal certainty regarding the ownership of HKI, but also can be pledged as collateral loans in International banking. ${ }^{35}$

Altitude Capital Partners is a US \$ 250 million private investment fund roomates Invests in IP assets and IP-focused companies, covering patents, trademarks, copyright and royalty streams. The company works with individual IP owners, as well as small and large IP-holding companies. In February 2007, Altitude invested in DeepNines, a network security solutions provider with returns linked to repayment from DeepNines' IP proceeds and secured by company assets. In April 2008, Altitude paired with Goldman Sachs \& Co. to invest US \$ 11 million in Intrinsity, Inc., a Texas-based technology company designing processor IP cores. ${ }^{36}$

Thailand's new Business Security Act (effective July 2016) Allows Borrowers Reviews their IP assets to use as collateral in securing loans, while retaining the right to possess and to put such collateral to commercial use during the secured period. Thailand's Business Security Act BE 2558 (2015) ( "the Act") Became effective on July $2,2016 .^{37}$

Dutch Patent Office (Octrooiencentrum Nederland). Benelux Intellectual Property Office (Bureau voor de Intellectuele Benelux Eigendom). Furthermore, one should not assume intangible assets are of secondary importance relative to tangible assets. On the Contrary, intangibles and tangibles are complementary assets, eg an assembly line that produces a Certain products using patented technology; a shop that produces a luxury brand of watches. In some cases, exclusion rights of intangibles imply higher priority than tangible assets. ${ }^{38}$

While intangibles have been used as a "floating charge" rate in junk bond contracts from as early as the 1980 s, extending credit on intangibles by collateralizing separable and contractible intangibles emerged in the mid1990s. For example, in 2001 Bank of America underwrote a term loan of \$ 350 million for the Levi Strauss that was collateralized by the company's trademarks. The deal further included a revolving credit line secured by the company's inventory. The company used Reviews These funds to reduce its borrowing costs, restructure its debt and lines.Moreover redesign of its core business, in 2003 the company refinanced its debt by pledging again its trademarks as collateral for a new term loan of $\$ 500$ million. Similarly, Astrazeneca, Ann Taylor, and GIK Worldwide are some of the companies that pledged Reviews their intellectual property to raise credit. (Anis M: 2017). Based on Bank Indonesia Regulation Number 14/15/PBI/2012 concerning Asset Quality Rating for Commercial Banks above shows that HKIs have not been entered as collateral accounted for as a deduction in the PPA. In some countries items, namely Bangladesh, India, Cambodia, Canada, China, Kenya, Malaysia, the US (Texas) HKI is already Recognized As collateral, as an example ${ }^{39}$ :

1. India: LT Foods, using the trademark 'Daawat' (rice packaging) as collateral in a loan of $£ 50$ million to acquire a competitor company based in the USA.

2. USA: In 2006, Ford Motor Company offers its intellectual property, trademarks Including Ford and the entire domestic tangible assets to Obtain loans amounting to US \$ 23 billion.

3. China: In 2008, the Chinese government started a pilot project of use of HKI (Patent) as collateral loans are backed by insurance. Until 2013, the pilot project has covered 29 regions with a total value of outstanding loans amounted to CNY25.4 billion. 
4. Malaysia: In 2013, the Malaysian government allocated a budget of RM 200 million for the Malaysian Debt Ventures Bhd (MDV) to develop HKI Financing Guarantee Scheme. The financing scheme is for SMEs engaged in the field of biotechnology innovation, green technology, and ICT (information, communication and technology). With this scheme, the government through the Credit Guarantee Corporation Malaysia provide interest subsidy of $2 \%$ and a guarantee of $50 \%$.

it appears likely that the IP values are increasing, in part due to the fact that the US economy continues to shift from a manufacturing-based economy to a servicebased. Evidence: services accounted for 41 percent of the Gross Domestic Product in 1960. By 2000, that number had grown to 55 percent and continued to steadily increase is to 58 percent by 2006 . The impact of this transformation Cleary has been demonstrated in the apparel industry where nearly all manufacturing is sourced from overseas and the assets that Werner in the US are primarily the rights to the trade names, the which are licensed to third parties. Examples of this business model include publicly traded companies such as Iconix Brand Group, Inc., Cherokee Inc., and NexCen Brands, Inc. A Similar business model exists for the licensing of patents, ${ }^{40}$ and the patented licensing industry is estimated to generate $\$ 100$ billion in successfully and security. ${ }^{41}$

While using intellectual property rights as collateral is a complicated process, doing so can be very worthwhile. IP rights borrower can afford a substantial value with roomates to secure a financing. For example, According to Interbrand's Best Canadian Brands 2010 guide, the Canadian Tire brand was worth Approximately $\$ 1.9$ billion, and the Tim Hortons brand at Approximately $\$ 2.6$ billion. With the benefit of experienced legal advice it is possible to use IP rights as collateral both successfully and securely. ${ }^{42}$

To mitigate conflicts of interest with less senior lenders upon borrower's bankruptcy, the collateral interest in intangibles was first lien and usually included all separable intangibles (for example, trademarks, customer lists, patents and / or copyrights related to a product brand or the firm's operations), as well as tangible assets. However, over the last few years, some loans have been secured solely by intangibles, as this innovation proved to be valuable, and lenders became more confident on Estimating liquidation value of intangible assets. ${ }^{43}$

\section{CONCLUSION}

HKI plays an important role which is one of the well-being of a nation, which is a moving object that is intangible, HKI also has economic value and be exclusive (meaning that his work of new, or expansion of existing ones, has economic value, can be applied in industrial world, has economic value, can be applied in the industrialized world have commercial value and can be used as assets). Classification of trademarks as places are trademarks Fiduciary is one of the objects of intellectual property rights set forth in the Act No. 20 of 2016 concerning the brand and geographical indications. Intellectual Property as the right material, which can be divided means can be transferred in whole or in part to any other party. Transfer whole or in part is shown by actions taken in connection with the exercise of the right, through the Heritage; Grant; Will; Written agreement; or other causes that are justified by law. With such classification trademark qualifies as one of the objects fiduciary. In some developed countries, particularly the United States has implemented the potential of intellectual property, especially trademark's function as a powerful object fiduciary security, such as KFC, Starbucks, Coca-cola, etc.

\section{ACKNOWLEDGMENT}

The grateful goes to Ministry of Research Technology and Higher Education of the Republic of Indonesia in particular Prof. Dr. Karna Ocky Radjasa, M.Sc. Director of Research and Community Services, which has provided research grants, as well as Chief LPPM Unissula, Dr. Heru Sulistyo, SE, Msi which has facilitated the realization of this study.

\section{REFERENCES}

1 M. Irsan Nasrudin and Indra Surya, 2008, Legal Aspects of Capital Markets of Indonesia, Kencana, Jakarta, p.77.

2 Explanation of Act No. 4 of 1996 on Mortgage

3 Article 1 paragraph 2 of Act No. 21 of 2008 concerning Islamic Banking

4 AP. Parlindungan, 1996, Mortgage Act, Mandar Maju, Bandung, p.2.

5 Sri Soedewi Masjchoen Sofwan, 1980, Legal Security in Indonesia: Principles of Security and Security Law Individual, Liberty, Yogyakarta, p.45

6 Kurniawan, R. ,2017, Effect of environmental disclosures on environmental performance of manufacturing, mining and plantation companies listed in Indonesian stock exchange. Arthatama: Journal of Business Management and Accounting, 1 (1), 6-17.

7 Ibid.

8 Anis Mashdurohatun, Hayyan Ul Haq ,Sony Zulhuda, Social Function Reconstruction Of Intellectual Property Rights (Ipr) Based On Justice Values ,International Journal of Law Reconstruction Volume I, Issue 1, September 2017,page.141

9 Anis Mashdurohatun \& M. Ali Mansyur, Product Capabilities Dynamic on Industrial Design Carved Wood in Small and Medium Enterprises (SMES) Jepara Furniture in Promoting the Protection of Intellectual Property Rights, International Journal of Applied Engineering Research ISSN 0973-4562 Volume 12, Number 19 (2017) page. 8217.

10 John W. Creswell,2013, Qualitative Inquiiry and Reserch Design, Sage, alih bahasa oleh Ahmad Lintang Lazuardi, 2014, Penelitian Kualitatif dan Desain Riset Memilih di Antara Lima Pendekatan, Pustaka Pelajar, Yogyakarta, p.59

11 Sulistyowati Irianto dan Shidarta, 2013, Ragam-ragam Penelitian Hukum dalam buku Metode Penelitian Hukum Konstelasi dan Refleksi, Yayasan Pustaka Obor Indonesia, Jakarta,p.122.

12 Sabian Utsman, 2014, Metodologi Penelitian Hukum Progresif, Pustaka Pelajar, Yogyakarta, p. 107. 
13 Djaja S. Meliala, 2008, Perkembangan Hukum Perdata Tentang Benda Dan Hukum Perikatan, Nuansa Aulia, Bandung, p.32.

14 Michael Grynberg, A Defense of the Disparagement Trademark Bar, 126 YLJF178 (2016), The Yale Law Journal Vol.126 / 2016-2017. ISSN: 00,440,094. http: //www.yalelawjournal.org/forum/a-trademark-defense-of-thedisparagement-bar.

15 J. Satrio, 2002, Hukum Jaminan Hak Jaminan Kebendaan Fidusia, Citra Aditya Bakti, Bandung, p. 12-13.

16 Sri Soedewi Masjchoen Sofwan, 1980, Hukum Jaminan di Indonesia, Pokok-Pokok Hukum Jaminan dan Jaminan Perseorangan, Liberty, Yogyakarta, p.47

17 Sentosa Sembiring, 2012, Hukum Perbankan, Revised Edition, Mandar Maju, Bandung, p. 221

18 Mohammad Djumhaud, 1993, Hukum Perbankan di Indonesia, Citra Aditya Bakti, Bandung, p. 240

19 Salim HS, 2004, Perkembangan Hukum Jaminan Di Indonesia, ed.I, PT. Raja Grafindo Persada, Jakarta, p.57.

20 Munir Fuadi 2005, Pengantar Hukum Bisnis, Citra Aditya Bakti, Bandung, p.151.

21 Salim HS, Ibid., p.55.

22 Gunawan widjaja \& Ahmad Yani, 2003, Jaminan Fidusia, ed.III, Raja Grafindo Persada, Jakarta, p.7

23 A. Hamzah and Senjun Manullang, 1987, Perkembangan Hukum Jaminan Di Indonesia, Indhill Co., Jakarta, p.37.

24 Ibid., p.3.

25 Gunawan Widjaja and Ahmad Yani, Op.Cit., p.113.

26 Salim HS, Ibid., p.57.

27 Achmad Busro, et al, Quo Vadis Copyright As Fiduciary Guarantee In Indonesian Legal Arrangement, Journal of Legal, Ethical And Regulatory Issues, Volume 21, Issue 2, 2018, 1544-0044-21-2-179, P. 2.

28 Anis Mashdurohatun, Mengembangkan Fungsi Sosial Hak Cipta Indonesia (Suatu Studi Pada Karya Cipta Buku), UNS Press, Surakarta,2016.

29 Ahmad Busro, loc.cit.

30 Adrian Sutedi, 2006, Implikasi Hak Tanggungan Terhadap Pemberian Kredit Oleh Bank dan Penyelesaian Kredit Bermasalah, Cipta Jaya, Jakarta, p. 12-13.

31 Anis Mashdurohatun, Constructing And Developing The Social Function Principles In Utilising Copyright Products Related To The Fundamental Rights, South East Asia Journal Of Contemporary Business, Economics And Law, Vol. 7, Issue 4 (Aug.) ISSN 2289-1560. 2015. P.87.

32 Philip Kotler, 1997, "The Marketing of Nations, A Strategic Approach to Building Wealth Nations", The Free Press New York, p. 24.

33 Lanning G. Bryer, Scott J. Lebson, Intellectual Property Assets In Mergers \& Acquisitions, published in 2002 by John Wiley \& Sons publication. This book is available online at www.amazon.com or www.wiley.com.p. 2.

34 Anis Mashdurohatun, The Concept Of Developing Intangibles Intellectual Property Rights As Collateral To Banks In Indonesia, Presented in the 3rd International Conference "Legal Development In Various Countries" held by Faculty of Law, Sultan Agung Islamic University on 5 September 2017.

35 Bisnis Indonesia, China and the United Nations Successfully Enforce IPR Certification (Brand) as Collateral For Bank 36 Loans, Monday, August 23, 2010, p.1.

http://www.wipo.int/wipo_magazine/en/2008/05/article 0001.html.

37 Suebsiri Taweepon and Ploynapa Julagasigorn, 2017, (Tilleke \& Gibbins - Thailand), Using IP as collateral in Thailand,
March 20, | E-News - Articles https://aippi.org/noshow/using-ip-as-collateral-in-thailand/

38 Sophia Longman, 2015, Intellectual Assets And Coporate Finance, Graduate Program In Business Administration, The Ohio State University, p. 3.

39 Yunita Resmi Sari, Director of Development of SMEs BI, "Pushing Banking Making Assets IPR as a tool Collateral with due regard to the principle of prudence", Workshop About Setup Regulation of Intellectual Property Rights as a Tool Collateral In the System of National Law, Jakarta, $26 \mathrm{~s} /$ d March 28, 2014, look in Trisadini Prasastinah Usanti, Agus Sujatmiko, Execution Of Trademark As Collateral Object Of Credit Bank, GSTF Journal of Law and Social Sciences (JLSS) Vol.6 1, 2017, p. 3.

40 Jay Eisbruck, Moody's Investors Service, New York, NY "Credit analysis of patent and trademark royalties ecuritisation: a rating agency perspective", Building IP Value 2005 look Inclusive Darin Neumyer, Of Using Intellectual Property And Intangible Assets As Collateral, The secured lenders jan / feb 2008, p. 44.

41 Wing T. Yan, Patents, Trade-marks, and Copyrights as Collateral, https://nelligan.ca/article/business-law/patentstrade-marks-and-copyrights-as-collateral/

42 Ibid.

43 Loumioti, Maria, The Use of Intangible Assets as Collateral Loan (November 1, 2012). Available at SSRN:https://ssrn.com/abstract=1748675 or http://dx.doi.org/10.2139/ssrn.1748675 , p. 35 